\title{
Further genetic evidence for the reproductive isolation of green sea anemone Actinia prasina Gosse from common intertidal beadlet anemone Actinia equina (L.)
}

\author{
A. M. Sole-Cava \& J. P. Thorpe \\ Department of Marine Biology, University of Liverpool, Port Erin, Isle of Man, United Kingdom
}

\begin{abstract}
Earlier work on Actinia indicated that a green morph, which has been described as $A$. prasina Gosse, is genetically distinct from the more common A. equina (L.). Sympatric populations of green and other morphs of Actinia were obtained from Fleshwick Bay (Isle of Man) and compared by enzyme electrophoresis and by nematocyst analysis. No nematocyst differences were found, but allele frequencies at several enzyme loci differed significantly. It is concluded that at Fleshwick Bay A. prasina is genetically distinct from $A$. equina and is a valid species
\end{abstract}

\section{INTRODUCTION}

The intertidal sea anemone Actinia equina (L.) is abundant on rocky shores throughout the British Isles. Its range extends at least over most of the Atlantic and Mediterranean coasts of Europe and North Africa (Stephenson 1935, Schmidt 1971, Manuel 1981), but exact geographical limits are unclear, particularly since the species is also found in South Africa (Stephenson 1935). It is ecologically very important and consequently has been studied extensively and in many areas.

Actinia equina is highly variable both in colour and morphology (Cocks 1850, Tugwell 1856, Gosse 1860, Stephenson 1935, Schmidt 1971, Manuel 1981) and in the past this has led to considerable taxonomic debate. Several early workers gave specific status to a variety of colour morphs (Templeton 1836, Johnston 1847 , Dalyell 1848, Cocks 1850, Tugwell 1856, MilneEdwards 1857), but throughout most of this century all have generally been considered conspecific (e.g. Stephenson 1935, Schmidt 1971, Campbell 1976).

Until recently the only taxonomic scheme in general use was that of Stephenson (1935), who considered Actinia equina to be a single species with just 2 varieties, which he called var. mesembryanthemum and var. fragacea. On the basis of biochemical and other evidence Stephenson's var. fragacea was raised to specific status by Carter \& Thorpe (1981) and is now known as A. fragacea Tugwell, whilst his var. mesembryanthemum, therefore, becomes simply Actinia equina (see Manuel 1981).

Following Carter \& Thorpe (1981) other biochemical genetic studies have investigated the structure of gene pools in Actinia equina (e.g. Orr et al. 1982, Quicke \& Brace 1983, 1984, Quicke et al. 1983) and in particular Haylor et al. (1984) have shown that a certain green morph is reproductively isolated from other sympatrically occurring morphs of the species. It has been proposed (Haylor et al. 1984) that this particular green colour morph should be raised to specific status using the name A. prasina Gosse (1860).

However, the results of Haylor et al. (1984) were for a single locality only and it is at present unclear whether, at other areas where they occur, green morphs are likely to be reproductively isolated from other sympatric Actinia equina. The object of the present study was to use enzyme electrophoresis to investigate the genetic structure of a population of $A$. equina from another sampling locality and to establish whether here also the reproductive isolation of the green colour morph [A. prasina Gosse (1860) sensu Haylor et al. (1984)] was maintained as previously described by Haylor et al. (1984). 
Enzyme electrophoresis is a very useful technique for systematic studies (reviews by e.g. Avise 1974, Gottlieb 1977, Ferguson 1980, Thorpe 1982, 1983, Ayala 1983) and has been used previously to reveal cryptic speciation in various sea anemones (e.g. Carter \& Thorpe 1981, Bucklin \& Hedgecock 1982, Haylor et al. 1984, Sole-Cava et al. 1985) as well as in several other groups (e.g. Laing et al. 1976, Steiner et al. 1977, Thorpe et al. 1978a, b, Thorpe \& Ryland 1979. Thorpe \& Mundy 1980, King et al. 1986, Sole-Cava \& Thorpe 1986a).

\section{MATERIALS AND METHODS}

Samples of Actinia equina (red or brown) and putative $A$. prasina (green) were collected intertidally from Fleshwick Bay (Isle of Man). This was one of the sampling sites used by Haylor et al. (1984) for their ecological work on Actinia, but it is about $2 \mathrm{~km}$ (about $5 \mathrm{~km}$ along the shore line) north of the site in Port Erin Bay from which their samples were obtained for electrophoresis. As A. equina is known to reproduce asexually by releasing internally brooded offspring (Orr et al. 1982) all the anemones collected were from at least $2 \mathrm{~m}$ apart in order to reduce the probability of sampling individuals from the same clone. Samples were taken from throughout the lower intertidal zone 0.5 to $3 \mathrm{~m}$ above chart datum). Anemones with bright pink pedal discs were avoided because it has been suggested (Quicke et al. 1983, Haylor et al. 1984) that these may show genetic differences from other Actinia. All the Actinia collected were maintained alive in running seawater in the laboratory until required for electrophoresis.

Electrophoresis was carried out using standard horizontal starch gel techniques (see e.g. Gordon 1975 , Harris \& Hopkinson 1978, Ferguson 1980). Gels used $12.5 \%$ starch (Sigma Chemical Co., Poole, Dorset, England). Details of buffer systems and sample sizes are given with the results in Table 1 . Tissue samples were taken from the oral disc and column of each anemone and were homogenized in not more than an equal volume of distilled water. Staining methods followed those of Shaw \& Prasad (1970) and Harris \& Hopkinson (1978). For further details of electrophoretic methods used see Haylor et al. (1984), Sole-Cava et al. (1985) and Sole-Cava (1986).

Nematocyst analysis was carried out on 6 Actinia equina and 6 green Actinia. Comparisons were made for 4 types of tissue (mesenteric filaments, actinopharynx, acrorhagi, tentacles). Nematocysts were classified using standard terminology (Weill 1934, Carlgren 1949, Hand 1955). Measurements were made of 20 nematocysts of each type present in each tissue in each anemone.
Table 1. Actinia. Gene frequencies over 18 loci in populations of $A$. equina and green Actinia. Buffer systems used are: 1 Tris-Citrate, pH 8.0 (Ward \& Beardmore 1977); 2. Tris-Citrate, pH 7.0 (Shaw \& Prasad 1970); 3, Discontinuous Tris-Citrate/ Borate (Poulik 1957)

\begin{tabular}{|c|c|c|c|c|}
\hline Locus & Alleles & A. equina & $\begin{array}{l}\text { Green } \\
\text { Actinia }\end{array}$ & Buffer \\
\hline Acon & $\begin{array}{l}1 \\
2 \\
3 \\
n\end{array}$ & $\begin{array}{c}0.400 \\
0.567 \\
0.033 \\
15\end{array}$ & $\begin{array}{c}0.375 \\
0.625 \\
0.000 \\
4\end{array}$ & 1 \\
\hline Cat & $\begin{array}{l}1 \\
2 \\
n\end{array}$ & $\begin{array}{c}0.167 \\
0.833 \\
12\end{array}$ & $\begin{array}{c}0.500 \\
0.500 \\
15\end{array}$ & 1 \\
\hline Est & $\begin{array}{l}1 \\
2 \\
\mathrm{n}\end{array}$ & $\begin{array}{c}0.125 \\
0.875 \\
24\end{array}$ & $\begin{array}{c}0.000 \\
1.000 \\
17\end{array}$ & 2 \\
\hline Got-1 & $\begin{array}{l}1 \\
\mathrm{n}\end{array}$ & $\begin{array}{c}1.000 \\
15\end{array}$ & $\begin{array}{c}1.000 \\
18\end{array}$ & 1 \\
\hline Got-2 & $\begin{array}{l}1 \\
2 \\
3 \\
n\end{array}$ & $\begin{array}{c}0.773 \\
0.227 \\
0.000 \\
11\end{array}$ & $\begin{array}{c}0.618 \\
0.382 \\
0.000 \\
17\end{array}$ & 1 \\
\hline$H k-1$ & $\begin{array}{l}1 \\
2 \\
\mathrm{n}\end{array}$ & $\begin{array}{c}0.080 \\
0.920 \\
25\end{array}$ & $\begin{array}{c}0.176 \\
0.824 \\
17\end{array}$ & 1 \\
\hline$H K-2$ & $\begin{array}{l}1 \\
2 \\
3 \\
n\end{array}$ & $\begin{array}{c}0.650 \\
0.150 \\
0.200 \\
20\end{array}$ & $\begin{array}{c}0.214 \\
0.571 \\
0.214 \\
14\end{array}$ & 1 \\
\hline Lap & $\begin{array}{l}1 \\
2 \\
3 \\
4 \\
\mathrm{n}\end{array}$ & $\begin{array}{c}0.079 \\
0.763 \\
0.105 \\
0.053 \\
19\end{array}$ & $\begin{array}{c}0.083 \\
0.750 \\
0.167 \\
0.000 \\
18\end{array}$ & 3 \\
\hline$M d h-1$ & $\begin{array}{l}1 \\
2 \\
n\end{array}$ & $\begin{array}{c}0.059 \\
0.941 \\
17\end{array}$ & $\begin{array}{c}0.000 \\
1.000 \\
18\end{array}$ & 2 \\
\hline$M d h-2$ & $\begin{array}{l}1 \\
2 \\
3 \\
\mathrm{n}\end{array}$ & $\begin{array}{c}0.632 \\
0.316 \\
0.053 \\
19\end{array}$ & $\begin{array}{c}1.000 \\
0.000 \\
0.000 \\
18\end{array}$ & 2 \\
\hline Mpi & $\begin{array}{l}1 \\
2 \\
3 \\
n\end{array}$ & $\begin{array}{c}0.125 \\
0.750 \\
0.125 \\
24\end{array}$ & $\begin{array}{c}0.091 \\
0.750 \\
0.159 \\
22\end{array}$ & 1 \\
\hline Pep & $\begin{array}{l}1 \\
2 \\
n\end{array}$ & $\begin{array}{c}1.000 \\
0.000 \\
23\end{array}$ & $\begin{array}{c}0.972 \\
0.028 \\
18\end{array}$ & 1 \\
\hline Pgd & $\begin{array}{l}1 \\
2 \\
n\end{array}$ & $\begin{array}{c}0.900 \\
0.100 \\
25\end{array}$ & $\begin{array}{c}0.810 \\
0.190 \\
21\end{array}$ & 1 \\
\hline Pgi-1 & $\begin{array}{l}1 \\
2 \\
n\end{array}$ & $\begin{array}{c}0.045 \\
0.955 \\
22\end{array}$ & $\begin{array}{c}0.045 \\
0.955 \\
22\end{array}$ & 1 \\
\hline Pgi-2 & $\begin{array}{l}1 \\
2 \\
n\end{array}$ & $\begin{array}{c}0.938 \\
0.063 \\
24\end{array}$ & $\begin{array}{c}0.841 \\
0.159 \\
22\end{array}$ & 1 \\
\hline$P g m$ & $\begin{array}{l}1 \\
2 \\
n\end{array}$ & $\begin{array}{c}0.478 \\
0.522 \\
23\end{array}$ & $\begin{array}{c}0.143 \\
0.857 \\
7\end{array}$ & 1 \\
\hline Sod & $\begin{array}{l}1 \\
n\end{array}$ & $\begin{array}{c}1.000 \\
17\end{array}$ & $\begin{array}{c}1.000 \\
7\end{array}$ & 1 \\
\hline Xod & $\begin{array}{l}1 \\
2 \\
n\end{array}$ & $\begin{array}{c}0.762 \\
0.238 \\
21\end{array}$ & $\begin{array}{c}0.706 \\
0.294 \\
17\end{array}$ & 1 \\
\hline
\end{tabular}




\section{RESULTS}

Useful results were obtained for a total of 18 enzyme loci. Allele frequencies for both Actinia equina and the green Actinia are shown in Table 1. Mean sample sizes per locus were 19.8 (range 11 to 25 ) and 16.2 (range 4 to 22) respectively. Enzyme nomenclature follows that of Harris \& Hopkinson (1978).

Allele 3 at the Got-2 locus is included in Table 1, although not found in either sample, because it is present in some other populations of Actinia. A probable second Sod locus found in some individuals in some other Actinia populations was not found in the present work (for discussion of SOD banding patterns see Haylor et al. 1984). The locus described here is the Sod-1 locus of Haylor et al. (1984)

Most loci showed no significant $(p=0.05)$ differences between the 2 sets of samples and no locus was diagnostic (i.e. showing an absolute difference; see e.g. Ayala 1983). However, at a few loci there were considerable differences; the most significant being $M d h-2$ $\left(\chi^{2}=16.36, \mathrm{df}=1, \mathrm{p}=5.34 \times 10^{-5}\right)$. Other loci showing significant differences were Cat $\left(\chi^{2}=8.08, \mathrm{df}=1\right.$, $\left.\mathrm{p}=4.68 \times 10^{-3}\right), H k-2\left(\chi^{2}=15.71, \mathrm{df}=2, \mathrm{p}=3.88 \times\right.$ $\left.10^{-4}\right)$ and $\operatorname{Pgm}\left(\chi^{2}=5.02, \mathrm{df}=1, \mathrm{p}=0.0251\right)$. Est could not be tested by $\chi^{2}$, but a binomial test on the distribution of Allele 1 was significant ( $p=0.0402$ ). Over the 4 loci Mdh-2, Cat, Hk-2 and Pgm the overall $\chi^{2}$ was extremely significant $\left(\chi^{2}=45.17, \mathrm{df}=5, \mathrm{p}=1.36 \times\right.$ $10^{-8}$ ).

No locus in either species showed any significant $(p=0.05)$ deviation from Hardy-Weinberg expectations, but, given the general weakness of tests of fit to Hardy-Weinberg ratios on other than large samples sizes (see e.g. Lewontin 1958, Fairbairn \& Roth 1980), this is not surprising.

Various loci in both Actinia equina and A. prasina showed allele frequency differences when compared with the data of Haylor et al. (1984) and in some cases these differences are statistically significant. Such differences between Actinia populations are common and even over short geographical distances significant genetic differentiation between populations is to be expected. Reproductive isolation on a very localized scale and absence of significant gene flow between adjacent populations are apparently basic features of the population structure in Actinia.

Results of the nematocyst analysis are summarized in Table 2. Analysis of variance (Sokal \& Rohlf 1981) indicates that there are no significant $(p=0.05)$ differences between Actinia equina and the green Actinia in size, type or distribution of nematocysts for any tissue.

\section{DISCUSSION}

It is clear from the results of the present work (Table 1) that at Fleshwick Bay the green colour morph of Actinia shows substantial and highly significant differences in allele frequencies at some loci when compared to the far more abundant red and brown morphs of $A$. equina. These differences strongly indicate the existence of a barrier to gene flow between the green and other colour morphs of Actinia and, since all the anemones examined were from the same place (i.e. sympatric), it must, therefore, be concluded that the green Actinia are not conspecific with the other morphs of A. equina. Any possibility of the distortion of gene frequencies by asexual reproduction can be ruled out since none of the anemones used in the present work had the same genotype over all the loci examined and, therefore, no two of them could have originated from the same clone.

The conclusion that, at Fleshwick Bay, the green Actinia are a separate species provides strong support for the work of Haylor et al. (1984), who raised the green morph from the nearby Port Erin Bay to specific status as A. prasina Gosse. A comparison of green Actinia from the 2 sites shows those from Fleshwick Bay to be apparently morphologically indistinguish-

Table 2. Actinia equina and green Actinia. Mean size $(\mu \mathrm{m})$ and standard deviation (SD) for each nematocyst type

\begin{tabular}{|llcccc|}
\hline Tissue & Nematocyst type & \multicolumn{2}{c}{ Actinia equina } & \multicolumn{2}{c|}{ Green Actinia } \\
& & Mean & SD & Mean \\
\hline Mesenteric filaments & Basitrich & 13.42 & 0.79 & 12.91 & 0.62 \\
& Microbasic p-mastigophore & 22.46 & 1.98 & 22.70 & 2.17 \\
Actinopharynx & Microbasic b-mastigophore & 35.04 & 2.80 & 33.62 & 4.27 \\
& Basitrich I & 24.38 & 1.91 & 24.51 & 2.12 \\
Acrorhagi & Basitrich Il & 13.88 & 1.43 & 14.10 & 1.34 \\
& Holotrich & 50.30 & 6.09 & 48.91 & 3.15 \\
Tentacles & Basitrich & 13.84 & 0.59 & 13.30 & 0.36 \\
& Basitrich & 22.41 & 1.93 & 21.68 & 1.30 \\
\hline
\end{tabular}


able from $A$. prasina on the basis of any visible external feature. This indicates that the green Actinia from Fleshwick Bay are probably also A. prasina and, therefore, it would appear that the species is not confined solely to Port Erin Bay and is likely to be present in various rocky bays on the Isle of Man and quite possibly also elsewhere (from the ecological data of Haylor et al. $1984 \mathrm{~A}$. prasina has a requirement for sheltered habitats and hence is less likely to be found on the open coast).

However, it may be of note that in the 2 bays where it has been found to date, Actinia prasina is the only green Actinia present and all specimens of the species are identical and uniform in colour. In other parts of Britain many different green morphs of Actinia have been described (see e.g. Tugwell 1856, Gosse 1860 , Stephenson 1935, Manuel 1981), some of which may or may not be conspecific with $A$. prasina. The original description of Actinia equina given by Linnaeus (1758, p.656) (= Priapus equinus Linnaeus 1758) is extremely brief and lacks any sort of useful description. No information on colour is given. In some areas Actinia are reported to occur in a continuous range of shades from pale green through olive to brown, whilst green specimens with brown tentacles and brown oral disc are also known (Gosse 1860). Without further work it is clearly not possible to draw any conclusions as to the taxonomic identity of green Actinia from other areas. It is improbable that all green morphs of Actinia will prove to be conspecific with $A$. prasina; some may be genuine green morphs of $A$. equina and others could be neither of these species.

The overall level of biochemical genetic differentiation between the 2 species of Actinia from Fleshwick Bay can be measured by any of a variety of indices of genetic distance or genetic similarity (Thorpe 1982). Estimates of the genetic identity, $I$, of Nei (1972) and genetic similarity, $S$, of Thorpe (1979) give figures of 0.955 and 0.870 respectively. These values are very similar to those $(0.91$ and 0.89 ) obtained by Haylor et al. (1984) for divergence between $A$. equina and $A$. prasina from Port Erin Bay, although they are higher than is usual for estimates between separate species. However, I values are affected by the numbers of alleles present (Thorpe 1979, 1982. Hillis 1984) and if, as in the present work, the populations concerned are highly polymorphic, estimates of $l$ can be unduly high.

From the data presented in Table 1 it can be seen that genetic variability in the Fleshwick Bay populations of both Actinia equina and $A$. prasina is unusually great (cf. Selander 1976, Nevo 1978). Estimates of mean observed heterozygosity per locus are 0.245 (expected 0.261 ) and 0.276 (expected 0.250 ) and proportions of loci polymorphic 0.833 and 0.722 respectively. However, in marine lower invertebrates (sea anemones and sponges) extremely high levels of genetic variability are apparently not uncommon (see e.g. Sole-Cava et al. 1985, Sole-Cava 1986, Sole-Cava \& Thorpe $1986 \mathrm{a}, \mathrm{b})$, although it is unclear why this should be so.

To assist with future identification of Actinia prasina it would be useful to have a type specimen available in some suitable collection. Unfortunately Gosse (1860) deposited no type material for his Actinia equina var. prasina and, therefore, we have deposited neotype specimens of what we consider to be $A$. prasina. These are in the collection of the British Museum (Natural History) in London and consist of a designated holotype (Specimen No. 1986. 12.17. 1) and 4 paratypes (Specimens 1986. 12. 17. 2-5).

\section{LITERATURE CITED}

Avise, J. C. (1974). Systematic value of electrophoretic data. Syst. Zool. 23: 465-481

Ayala, F. J. (1983). Enzymes as taxonomic characters. In: Oxford, G. S., Rollinson, D. (ed.) Protein polymorphism: adaptive and taxonomic significance. Academic Press, London, p. 3-26

Bucklin, A., Hedgecock, D. (1982). Biochemical genetic evidence for a third species of Metridium (Coelenterata: Actiniaria). Mar Biol. 66: 1-7

Campbell, A. C. (1976). Guide to the shallow seas of Britain and Europe. Hamlyn, London

Carlgren, O. (1949). A survey of the Phytodactiaria, Coralimorpharia and Actiniaria. K. Sven. Vetenskapsakad Handl. 1: 1-121

Carter, M. A., Thorpe, J. P. (1981). Reproductive, genetic and ecological evidence that Actinia equina var. mesembryanthemum and var. fragacea are not conspecific. J. mar. biol. Ass. U.K. 61: 79-93

Cocks, W. P. (1850). Contributions to the fauna of Falmouth. Rep. Cornwall Polytechnic Soc. 17: 94-95

Dalyell, J. G. (1848). Rare and remarkable animals of Scotland represented from living subjects: with practical observations on their nature, Vol 2. Van Voorst, London

Fairbairn, D. J., Roth, D. A. (1980). Testing genetic models of isozyme variability without breeding data: can we depend on the chi-square? J. Fish Aquat. Sci. 37: 1149-1159

Ferguson, A. (1980). Biochemical systematics and evolution. Blackie, Glasgow

Gordon, A. H. (1975). Electrophoresis of proteins in polyacrylamide and starch gels. North Holland, Amsterdam

Gosse, P. H. (1860). A history of the British sea anemones and corals. Van Voorst, London

Gottlieb, L. D. (1977). Electrophoretic evidence and plant systematics. Ann. Missouri Bot. Gard. 64: 161-180

Hand, C. (1955). The sea anemones of central California, Part 2. The endomyarian and mesomyarian anemones. Wasman J. Biol. 13: 37-99

Harris, H., Hopkinson, D. A. (1978). Handbook of enzyme electrophoresis in human genetics. North Holland, Amsterdam

Haylor, G. S., Thorpe, J. P., Carter, M. A. (1984). Genetic and ecological differentiation between sympatric colour morphs of the common intertidal sea anemone Actinia equina. Mar. Ecol. Prog. Ser 16: 281-290 
Hillis, D. M. (1984). Misuse and modification of Nei's genetic distance. Syst. Zool. 33: 238-240

Johnston, C. (1847). A history of the British zoophytes. Van Voorst, London

King, P. E., Thorpe, J. P., Wallis, G. P. (1986). A biochemical genetic and morphological investigation of the species within the genus Endeis Philippe (Pycnogonida; Endeidae) in Britain. J. exp. mar. Biol. Ecol. 98: 115-128

Laing, C. D., Carmody, G. R., Peck, S. B. (1976). How common are sibling species in cave inhabiting invertebrates? Am. Nat. 110: $184-189$

Lewontin, R. C. (1958). A general method for investigating the equilibrium of gene frequency in a population. Genetics 43: $419-434$

Linnaeus, C. (1758). Systema naturae per regna tria naturae, secundum classes, ordines, genera, species, cum characteribus, differentiis, synonymis, locis. Tomus I. Laurentii Salvii, Homiae

Manuel, R. L. (1981). British Anthozoa. Academic Press, London

Milne-Edwards, H. (1857). Histoire naturelle des coralliaires ou polypes proprement dits, Vol. 1. Paris

Nei, M. (1972). Genetic distance between populations. Am. Nat. 106: 283-292

Nevo, E. (1978). Genetic variation in natural populations: patterns and theory. Theor. Pop. Biol. 13: 121-177

Orr, J., Thorpe, J. P., Carter, M. A. (1982). Biochemical genetic confirmation of the asexual reproduction of brooded offspring in the sea anemone Actinia equina. Mar. Ecol. Prog. Ser. 7: 227-229

Poulik, M. D. (1957). Starch gel electrophoresis in a discontinuous system of buffers. Nature, Lond. 180: 1447-1479

Quicke, D. L. J., Brace, R. C. (1983). Phenotypic and genotypic spacing within an aggregation of the sea anemone, Actinia equina. J. mar. biol. Ass. U.K. 63: 493-515

Quicke, D. L. J., Brace, R. C. (1984). Evidence for the existence of a third, ecologically distinct morph of the anemone, Actinia equina. J. mar. biol. Ass. U.K. 64: 531-534

Quicke, D. L. J., Donoghue, A. M., Brace, R. C. (1983). Biochemical genetic and ecological evidence that red/ brown individuals of the anemone Actinia equina comprise two morphs in Britain. Mar. Biol. 77: 29-37

Schmidt, H. (1971). Taxonomie, Verbreitung und Variabilität von Actinia equina Linne 1756 (Actiniaria: Anthozoa). Z. zool. Syst. Evolutionsforsch. 9: 161-169

Selander, R. K. (1976). Genetic variation in natural populations. In: Ayala, F. J. (ed.). Molecular evolution. Sinauer Associates, Sunderland, Mass., p. 21-45

Shaw, P. R., Prasad, R. (1970). Starch gel electrophoresis of enzymes - a compilation of recipes. Biochem. Genet. 4: 297-320

Sokal, R. R., Rohlf, F. J. (1981). Biometry. The principles and practice of statistics in biological research, 2 nd edn. Freeman, San Francisco
Sole-Cava, A. M. (1986). Studies of biochemical systematics and taxonomy in coelenterates and sponges. Ph. D. thesis, University of Liverpool, Port Erin, Isle of Man

Sole-Cava, A. M., Thorpe, J. P. (1986a). Genetic differentiation between morphotypes of the marine sponge Suberites ficus (Demospongiae: Hadromerida). Mar. Biol. 93: $247-254$

Sole-Cava, A. M., Thorpe, J. P. (1986b). High levels of genetic variation in marine sponges. In: Hartman, W. D., Ruetzler, $\mathrm{K}$. (ed.) Proceedings of the Third International Conference on the Biology of Sponges. Smithsonian Inst., Washington (in press)

Sole-Cava, A. M., Thorpe, J. P., Kaye, J. G. (1985). Reproductive isolation with little genetic divergence between Urticina (= Tealia) felina and $U$. eques (Anthozoa: Actiniaria). Mar. Biol. 85: 279-284

Steiner, W. W. M., Lisowski, E. A., Ostebur, D. (1977). Biochemical differences in sympatric colour morphs of an aquatic isopod (Asellus brevicaudata) Comp. Biochem. Physiol. 56: 371-374

Stephenson, T. A. (1935). The British sea anemones, Vol. 2. Ray Society, London

Templeton, R. (1836). A catalogue of the species of rayed animals found in Ireland. Nat. Hist. Mag. 9: 301-305

Thorpe, J. P. (1979). Enzyme variation and taxonomy: the estimation of sampling errors in measurements of interspecific genetic similarity. J. Linn. Soc. (Biol.) 11: 369-386

Thorpe, J.P. (1982). The molecular clock hypothesis: biochemical evolution, genetic differentiation and systematics. Ann. Rev. Ecol. Syst. 13: 139-168

Thorpe, J. P. (1983). Enzyme variation, genetic distance and evolutionary divergence in relation to levels of taxonomic separation. In: Oxford, G. S., Rollinson, D. (ed.). Protein polymorphism: adaptative and taxonomic significance. Academic Press, London, p. 131-152

Thorpe, J. P., Beardmore, J. A., Ryland, J. S. (1978a). Genetic evidence for cryptic speciation in the marine bryozoan Alcyonidium gelatinosum. Mar. Biol. 49: 27-32

Thorpe, J. P., Mundy, S. P. (1980). Biochemical genetics and taxonomy in Plumatella emarginata and P. repens (Bryozoa: Phylactolaemata). Freshwat. Biol. 10: 361-366

Thorpe, J. P., Ryland, J. S. (1979). Cryptic speciation detected by biochemical genetics in three ecologically important species of intertidal bryozoans. Estuar. coast. mar. Sci. 8: 395-398

Thorpe, J. P., Ryland, J. S., Beardmore, J. A. (1978b). Genetic variation and systematics in the marine bryozoan Alcyonidium mytili. Mar. Biol. 49: 343-350

Tugwell, G. (1856). A manual of sea-anemones commonly found on the English coast. Van Voorst, London

Ward, R. D., Beardmore, J. A. (1977). Protein variation in the plaice (Pleuronectes platessa). Genet. Res. 30: 45-62

Weill, R. (1934). Contribution a l'etude des cnidaires et de leurs nematocystes. Trav. Stn Zool. Wimereux 10: 1-702 